\title{
Two Translations of Rafal Podraza: Our Last Waltz and Reckoning
}

\section{Our Last Waltz}

\section{$\underline{\text { Nasz Ostatni Walc }}$}

Dziś chodź - chodź, trzeba spróbować

Zatrzymać w tańcu czas

Dziś chodź - chodź, bo w takt muzyki

Sam zegar zwolnił marsz

Jeszcze noc w twych ramionach trwa Jeszcze słyszę twój głos

To dla nas jest ta muzyka -

Dla nas ona dziś gra

Więc tańczmy bosko szaleni

Wiec tańczmy w siebie wtuleni

Nie wiedząc co niesie nam świat -

Co nam przyniesie znów świat

Więc tańczmy bosko zmęczeni

Tak w siebie - w siebie wpatrzeni

Nie wiedząc co niesie nam świat

$\mathrm{Z}$ jutrem przyniesie świat

Już wiem - wiem nikt nie poprosi

Do tańca więcej nas

Ja wiem - wiem to pożegnanie

To nasz ostatni walc

Jeszcze noc szalona trwa

Wciąż słyszę jeszcze twój głos

To dla nas jest ta muzyka -

Dla nas ona dzisiaj gra $[\ldots]$

\section{Our Last Waltz}

Come here - here, we must try

Suspend time in dance

Come here - here, see the clock has

Paused its musical march

The night lingers young in your arms

I still hear your voice

This music is just for us -

This music is ours alone

So let's dance in heavenly madness

Let's dance in close embrace

Not knowing what's ahead of us -

What awaits us in life

So let's dance in leaden bliss

Gazing at one another - at each other

Not knowing what's ahead of us -

What will tomorrow bring

I know - know, no one will ask

Me to dance anymore

I know - know, it's our farewell

It's our last waltz

The reckless night is still young

I still hear your voice

This music is just for us -

This music is ours alone [...]

\footnotetext{
${ }^{1}$ Polish text by Rafał Podraza, music by Jerzy Petersburski jr.
} 


\section{Reckoning}

\begin{tabular}{|c|c|}
\hline$\underline{\text { Bilans }}^{2}$ & Reckoning \\
\hline I nadszedł czas & The time has come \\
\hline Pożegnać się & To say goodbye \\
\hline Rozliczyć każdą noc - & Settle every night - \\
\hline Rozliczyć każdy dzień & Settle each day \\
\hline Jak długo można & How long can I \\
\hline Wierzyć w tyle kłamstw & Accept so many lies \\
\hline Wykrętów, bzdurnych prawd & Pretexts, hollows truths \\
\hline Tłumaczeń - dosyć mam & Excuses - I've had enough \\
\hline Proszę zrozum & Please know \\
\hline Że nie kocham ciebie już & I don't love you anymore \\
\hline Grzecznie odejdź stąd & Simply go away \\
\hline Naszą miłość dawno & Our love has vanished \\
\hline Przykrył gruby kurz & Under heavy dust long ago \\
\hline Dzisiaj opuść mój ląd & Leave my kingdom today \\
\hline Zrozum wreszcie & Just realize that \\
\hline Że nie kocham ciebie już & I don't love you anymore \\
\hline Grzecznie odejdź stąd & Simply go away \\
\hline Naszą miłość dawno & Our love has vanished \\
\hline Przykrył gruby kurz & Under heavy dust long ago \\
\hline Dzisiaj opuść mój ląd & Leave my kingdom today \\
\hline Już nie lej dziś & Stop shedding now \\
\hline Tych niby łez & These feigned tears \\
\hline Pomyśleć mogłaś wcześniej & You could've figured it out \\
\hline Szans było wiele więc & You've had your many chances \\
\hline Zaufaj mi to ma swój sens & Just trust me that it all makes sense \\
\hline Ja pójdę swoją drogą & I will go my way \\
\hline Ty swoją pójdziesz też & You go yours \\
\hline Proszę zrozum & Please understand \\
\hline Że nie kocham ciebie już & I don't love you anymore \\
\hline Grzecznie odejdź stąd & Simply go away \\
\hline
\end{tabular}

${ }^{2}$ Polish text by Rafał Podraza, music by Jerzy Petersburski Jr. 
Transc UlturAl, vol. 9.1 (2017), 168-170.

http://ejournals.library.ualberta.ca/index.php/TC

\begin{tabular}{|l|l|}
\hline Naszą miłość dawno & Our love has vanished \\
Przykrył gruby kurz & $\begin{array}{l}\text { Under heavy dust long ago } \\
\text { Dzisiaj opuść mój ląd }\end{array}$ \\
Zrozum wreszcie & Just realize that \\
Że nie kocham ciebie już & I don't love you anymore \\
Grzecznie odejdź stąd & Simply go away \\
Naszą miłość dawno & Our love has vanished \\
Przykrył gruby kurz & Under heavy dust long ago \\
Dzisiaj opuść mój ląd & Leave my kingdom today \\
& \\
\hline
\end{tabular}

